\title{
MIЖHAPOДHE ПPABO
}

УДК 340.134

DOI https://doi.org/10.32838/TNU-2707-0581/2021.4/19

\section{Вайцеховська O.P.}

Чернівецький національний університет імені Юрія Федьковича

Руденко О.В.

Чернівецький національний університет імені Юрія Федьковича

\section{ЄВРОПЕЙСЬКИЙ СОЮЗ ЯК СУБ'ЄКТ МІЖНАРОДНОГО ФІНАНСОВОГО ПРАВА ТА ОСОБЛИВОСТІ ЙОГО ФІНАНСОВОГО ПРАВОПОРЯДКУ}

У статті проаналізовано правосуб'єктність Свропейського Союзу, яка отримала своє нормативно-правове закріплення з набранням чинності Лісабонського договору у 2009 роиі. Відповідно до положень иього Договору, СС наділений державами-членами повноваженнями в обсязі, необхідному для досягнення спільних иілей, які він може досягати належними засобами відповідно до наданих Договором повноважень.

Розглянуто особливості договірної правосуб'єктності СС, яка характеризує здатність створювати Союзом норми міжннародного права, включаючи фінансові. Схарактеризовано нормативно-правове закріплення договірної правосуб'єктності ЄС та прочедури укладення угод у валютній сфері. Проаналізовано особливості членства ЄС у міжнародних фінансових організаиіях, запропоновані різновиди представниитва в них держсав-членів СС і Європейського Союзу.

Досліджено особливості фінансового правопорядку СС, який трунтується на реалізаиї основоположних принципів вільного переміщення капіталів, товарів, послуг $і$ осіб, щзо знайшли найбільшого втілення в рамках Європейського Союзу, а ӥхнє запровадження і реалізачія у фінансовій сфері об'єктивно зумовлені потребами розвитку иього регіонального фінансового правопорядку відповідно до його статутних иілей.

Встановлено, що до особливостей фінансового правопорядку ЄС належсать: 1) неоднорідність нормативно-правового складника фінансового правопорядку $Є C$ - зона євро не охоплює територію всіх держав-членів СС, що створює різне нормативно-правове навантаження установчих договорів ЄС на монетарну політику урядів країн-членів $Є С$; 2) дуалістична природа фінансового права СС, норми якого, з одного боку, мають формально міжнароднодоговірне походження і регулюють відносини між державами-членами ЄС у сфері фінансів, а з іншого - мають пряму дію на фізичних та юридичних осіб; 3) до сучасних тенденцій у фінансовому правопорядку СС належать: взаємопроникнення наџіональних фінансових систем держав-членів СС, мінімізачія їхньої автономності, об'єднання фінансових ринків країн ЄC, формування глобального регіонального фінансового ринку ЄC.

Ключові слова: фінансовий правопорядок, міжнародне фінансове право Європейський Союз, міжнародна правосуб 'єктність СС.

Постановка проблеми. Порівняно 3 існуючими в міжнародному співтоваристві міжнародними міжурядовими організаціями Свропейський Союз - «це якісно нове інтеграційне об'єднання» $[1$, c. 13], правова природа якого до кінця не визначена, оскільки «під час створення інституційного механізму СС заради забезпечення рівноваги між наднаціональними і національними інтересами були використані елементи, властиві різним моделям організації влади (імперія, федерація, конфедерація, міжнародна організація)» [2, с. 381]. Союз $є$ унікальним 3 огляду на здатність створювати правові норми задля забезпечення досягнення визначених у статутних договорах цілей 
та ефективних механізмів забезпечення їхнього виконання як державами-членами, так і іншими суб' єктами міжнародного права [3, с. 53]. В рамках дослідження міжнародного фінансового правопорядку Свропейський Союз виступає, з одного боку, його суб'єктом (як й інші міжнародні організації), а з іншого - в якості особливого інтеграційного утворення має свій власний фінансовий правопорядок, який грунтується на первинних фінансових нормах права ЄС. 3 огляду на вищезазначене, питання правосуб'єктності ЄС та специфіки його фінансового правопорядку заслуговують особливої уваги.

Аналіз останніх досліджень і публікацій. Проблематика міжнародної правосуб'єктності ЄС виступала предметом правового аналізу більшості монографій та підручників, присвячених праву $\mathrm{EC}$, а також окремих статей, зокрема таких науковців, як О.А.Назаренко, К.В. Бережна, О.О. Гріненко, С.В. Толстов, О.І. Дікарєв та багатьох інших. Питання гармонізації та уніфікації фінансового законодавства країн $€ C$, а також інші особливості правового регулювання фінансової сфери відносин в $\mathrm{CC} \mathrm{розглядались} \mathrm{у} \mathrm{підручниках} \mathrm{з} \mathrm{Права} Є \mathrm{C}$ таких науковців, як В.І. Муравйов, Р.А. Петров, I.В. Яковюк та інших, зокрема у структурних частинах підручників, присвячених правовому регулюванню фінансових відносин СС; вільному руху капіталів, товарів, послуг і осіб; спільній митній та торговельній політиці; економічному та валютному союзу; податковому праву $\mathrm{EC}$; фіскальним заходам ЄС; Свропейському центральному банку та Рахунковій палаті ЄС тощо. Щодо особливостей правового статусу СС у міжнародному фінансовому праві та його фінансового правопорядку спеціальних монографічних досліджень у вітчизняній науці не проводилося.

Постановка завдання. Мета дослідження - здійснення правового аналізу міжнародної правосуб'єктності Європейського Союзу в міжнародному фінансовому праві та виявлення особливостей його фінансового правопорядку.

Виклад основного матеріалу дослідження. Проблема міжнародної правосуб'єктності Свропейського Союзу 3 моменту його створення в 1992 році привертає увагу дослідників в ЄС та за його межами. Громадянство, бюджет, що формується за рахунок власних джерел, інституційна система, порядок прийняття рішень i, врешті-решт, правова система sui generis у межах $€ С$ відрізняють Європейський Союз від інших міжнародних організацій сучасного світу, а його правовий статус важко характеризувати традицій- ними категоріями міжнародного права [3, с. 57]. У міжнародно-правовій літературі все частіше зазначається про виникнення нового виду правової системи - інтеграційної правової системи, яка певною мірою $є$ гібридною, але при цьому характеризується відмінними ознаками $[4$, с. 440$]$. Не вдаючись у рамках цього дослідження до дискусій навколо правової природи Європейського Союзу як міждержавного об'єднання особливого роду $[3 ; 5 ; 6]$, зупинимося тільки на питанні правового статусу ЄС у міжнародному фінансовому правопорядку.

3 набранням чинності у 2009 році Лісабонського договору (про реформування $\mathrm{CC}$ ) міжнародна правосуб'єктність Європейського Союзу отримала нормативно-правове закріплення. Відповідно до положень Договору про Європейський Союз [7] (ДСС), СС наділений державами-членами повноваженнями в обсязі, необхідному для досягнення спільних цілей (ст. 1), які він може досягати належними засобами відповідно до наданих Договором повноважень (ст. 3). Подібно до більшості міжнародних міжурядових організацій, діяльність ЄС грунтується на принципі «наданих повноважень» (ст. 5 ДСС). Проте такі повноваження не обов'язково випливають із конкретних положень договорів, а можуть також «матися на увазі», підтвердженням чого виступає судова практика та положення Договору про функціонування Європейського Союзу (ДФЄС). Відповідно до статті 352 цього Договору, «якщо дія Союзу виявиться необхідною в рамках політик, визначених Договорами, задля досягнення однієї з цілей, установлених Договорами, а Договори не визначають необхідних повноважень, Рада ... ухвалює належні заходи» [7]. Отже, Союз має власну «волю» та діє самостійно на міжнародній арені (відповідно до установчих актів), реалізовує власні права та обов'язки, створює правові норми та забезпечує їхнє виконання.

Один із важливих складників міжнародної правосуб'єктності - договірна правосуб'єктність, яка характеризує здатність створювати норми міжнародного права. Свропейський Союз може укладати міжнародні договори (обов'язкові для установ Союзу та держав-членів) 3 однією або кількома державами або міжнародними організаціями, якщо: 1) це передбачено Договорами; 2) укладання угоди $є$ необхідним для досягнення в рамках політик Союзу однієї із цілей, зазначених у Договорах; 3) це передбачено юридично обов'язковим актом Союзу; 4) це може вплинути на спільні правила або змінити їхню сферу засто- 
сування (ст. 216 ДФСС [7]). Процедура укладення міжнародних договорів $€ \mathrm{C}$ із третіми країнами чи міжнародними організаціями регулюється статтею 218 ДФЄС.

Протягом усього періоду співпраці України з ЄС було підписано низку міжнародних угод фінансового характеру, які переважно стосувалися фінансування 3 боку Союзу різного роду українських проектів та програм (наприклад, Угода про фінансування заходу «Програма підтримки енергоефективності в Україні - EE4 U-II» від 2018 року [8] та інші) або ж надання кредитів (наприклад, Кредитна Угода між Україною як Позичальником, Національним банком України як Фінансовим агентом Позичальника та Європейським Союзом як Кредитором від 2018 року [9]) .

У договірній практиці ЄС мають місце також змішані угоди, в яких одночасно беруть участь як $\mathrm{CC}$, так і держави-члени, а предметом регулювання виступають відносини, регламентація яких виходить за рамки повноважень, наданих СС і тих, що залишились у держав-членів $\mathrm{CC} \mathrm{(угоди} \mathrm{про}$ асоціацію, партнерство і співробітництво та інші). Такого роду угоди існують і в договірній практиці України та ЄС, а саме: Угода про асоціацію між Україною, з однієї сторони, та Європейським Союзом, Свропейським співтовариством із атомної енергії і їхніми державами-членами, з іншої сторони, від 2014 року [10]; Угода про партнерство та співробітництво між Україною і Європейськими співтовариствами та їхніми державамичленами від 1994 року [11] (втратила чинність).

Окремою статтею в розділі V ДФЄС (Міжнародні угоди) закріплено порядок укладення угод у валютній сфері. Відповідно до статті 219 ДФЄС, «Рада або за рекомендацією Європейського центрального банку, або за рекомендацією Комісії та після консультацій з Європейським центральним банком, намагаючись досягти консенсусу, що узгоджується з метою досягнення цінової стабільності, може укладати формальні угоди про систему курсів євро та валюти третіх держав», «може затверджувати, змінювати або скасовувати центральний курс євро в межах системи курсів обміну», «може формулювати загальні орієнтири політики обмінного курсу щодо цих валют». Також у статті зазначається: «якщо угоди з валютних питань та питань валютного регулювання потребують проведення переговорів між Союзом та однією або більшою кількістю третіх держав або з міжнародними організаціями, Рада за рекомендацією Комісії та після проведення консультацій з Європейським центральним банком приймає рішення щодо умов переговорів та стосовно укладання таких угод» [7].

Міжнародна договірна правосуб' єктність тісно пов'язана 3 правом набуття членства в міжнародних організаціях. Аналіз складу членів міжнародних фінансових організацій свідчить про наступні різновиди представництва держав-членів СС і Європейського Союзу: 1) змішана форма представництва, за якої учасником міжнародної організації виступає як $\mathrm{CC}$, так і державичлени. Наприклад, до складу учасників Групи 20, окрім країн-членів СС (наприклад, Німеччини, Італії, Франції), входить і Європейський Союз як колективний член організації; акціонерами (учасниками) Європейського банку реконструкції та розвитку, окрім 64 країн, виступає також Європейська комісія; 2) членство в міжнародній організації держав-членів ЄС супроводжується участю в роботі міжнародної організації інституції $\mathrm{CC}$ без права голосу (наприклад, у роботі Організації економічного співробітництва і розвитку бере участь без права голосу Свропейська комісія [12]); 3) членами міжнародної організації виступають тільки держави-члени $\mathrm{CC}$ (наприклад, Міжнародний валютний фонд).

Окрім укладення міжнародних угод, ще однією важливою формою реалізації міжнародної правосуб'єктності ЄС є встановлення дипломатичних відносин шляхом відкриття власних представництв у третіх країнах і при міжнародних організаціях, а також акредитації аналогічних представництв, що відкриваються цими країнами та організаціями при ЄС. Створення Європейської служби зовнішньополітичної діяльності сприяє формуванню в межах Союзу власного дипломатичного відомства, яке діє паралельно 3 дипломатичними відомствами держав-членів [13].

За загальним для міжнародних міжурядових організацій правилом, Свропейський Союз користується на територіях держав-членів привілеями та імунітетами, необхідними для виконання його завдань (ст. 343 ДФСС). Також у межах Лісабонського договору сформульовано міжнародну договірну та позадоговірну відповідальність ЄС (ст. 340 ДФСС).

Досліджуючи генезис міжнародної правосуб'єктності інтеграційних утворень, T. Короткий зазначає, що головною причиною сучасних інтеграційних процесів $є$ прагнення до економічної ефективності, особливо в умовах глобалізації, і сама інтеграція носить, насамперед, економічний характер. Фактично, продовжує науковець, з економічних причин відбувається част- 
кова відмова держав від суверенітету на користь конкурентоспроможності національної економіки за утворення інтеграційних об'єднань, причому участь в інтеграційних об'єднаннях є одночасно проявом та реалізацією суверенітету [14, с. 441].

Формування глобального економічного простору базується на основоположних принципах вільного переміщення капіталів, товарів, послуг, осіб, які в другій половині XX століття починають закріплюватися не тільки у внутрішньому національному законодавстві країн, але й на рівні законодавства регіональних інтеграційних об'єднань [15, с. 287]. Найбільшого втілення вказані принципи знайшли в рамках Європейського Союзу, а їх запровадження і реалізація у фінансовій сфері об'єктивно зумовлені потребами розвитку цього регіонального фінансового правопорядку відповідно до його статутних цілей.

Поряд зі спільною бюджетною та податковою політикою $С С$ свобода переміщення капіталу відіграє важливу роль у формуванні фінансового правопорядку СС. Формально свобода переміщення капіталу була проголошена 3 початку інтеграційного процесу, проте іï реальне втілення в життя відбулося після створення економічного та валютного союзу. Зазначена свобода передбачає можливість: вільно здійснювати фінансові операції, пов'язані $з$ інвестуванням; інвестувати в іншу державу; не повертати в країну свого первинного перебування інвестовані фінансові ресурси в розумний строк. Підтверджуючи абсолютний характер заборони на будь-які обмеження свободи переміщення капіталу в треті країни або з третіх країн, Лісабонський договір зазначає, що відхилення від норм щодо лібералізації руху капіталу до або з третіх країн можливе виключно шляхом одноголосного прийняття Радою відповідного рішення після консультації з Європарламентом (ст. 63 ДФСС) [7].

Як слушно зазначає Ф. Рочча, європейська інтеграція призвела до тріумфу вільної циркуляції капіталів [16]. Створення економічного і валютного союзу зумовило перехід від координації до гармонізації бюджетної і фінансової політики держав-членів $\mathrm{CC}$, що, на думку О. Петришина та В. Сала, дає підстави визнати економічний i валютний союз вищим ступенем економічної інтеграції, адже він передбачає передачу національними урядами інституціям ЄС компетенції в одному з найбільш чутливих для національної ідентифікації питань - у питанні регулювання грошової емісії і здійснення грошової політики $[15$, c. $305-306]$.
Поступове нарощування інституціями $\mathrm{EC}$ повноважень у фінансовій сфері, яке відбувалося протягом усього періоду європейської інтеграції, посилилося після останньої світової фінансової кризи. Загостривши проблему забезпечення життєдіяльності фінансової системи $\mathrm{CC}$, фінансова криза спонукала Європейський Союз до розширення сфери правового регулювання фінансовими інституціями $Є С$ та створення більш жорсткого механізму контролю фінансового сектору $\mathrm{EC}$, який би дозволяв на ранніх стадіях виявляти та ліквідовувати системні ризики. Об'єктивна реальність дестабілізації фінансового сектору ЄC під час фінансової кризи та нагальна необхідність застосування комплексу заходів із метою мінімізації іiї наслідків призвели до зміни правового статусу Європейського центрального банку в напрямку розширення його впливу як на наднаціональному, так і на національному рівнях, задля відновлення та стабілізації зони євро і допомоги національним урядам [15, с. 306].

Нині в рамках Європейського Союзу сформований специфічний регіональний фінансовий правопорядок, в якому держави-члени СС передали частину суверенних прав і повноважень у сфері бюджетної, валютної, емісійної та податкової політики наднаціональним інституціям СС та гармонізували своє національне законодавство у сфері фінансів. Унаслідок цього відбулося формування нормативно-правового підгрунтя фінансового правопорядку СС - системи фінансового права ЄС. Ядром нормативно-правової частини фінансового правопорядку ЄС виступають положення установчих договорів $\mathrm{CC}$ iз фінансових питань, які для інституцій ЄС та держав слугують основним вектором правотворчості в цій сфері. Ці основоположні правові норми разом із низкою директив та регламентів інституцій $€ \mathrm{C}$ із фінансових питань утворюють спільне для всіх держав-членів СС правове поле, в рамках якого діють суб'єкти фінансових правовідносин. Специфікою фінансового правопорядку $\mathrm{CC}$, зумовленою асиметрією держав-членів у різних формах співпраці, $\epsilon$ неучасть певних країн у виконанні статутних зобов'язань щодо вступу в європейську зону $[17$, c. 70$]$.

Висновки. До особливостей фінансового правопорядку ЄС належать:

1) неоднорідність нормативно-правового складника фінансового правопорядку $\mathrm{CC}$ - зона євро не охоплює територію всіх держав-членів $\mathrm{EC}$, що створює різне нормативно-правове навантаження установчих договорів СС на монетарну політику 
урядів країн-членів $\mathrm{CC} ; 2)$ дуалістична природа фінансового права $Є \mathrm{C}$, норми якого, з одного боку, мають формально міжнародно-договірне походження і регулюють відносини між державамичленами СС у сфері фінансів, а з іншого - мають пряму дію на фізичних та юридичних осіб (наприклад, установчі договори та регламенти ЄС). Це зумовлює специфічний суб’єктний склад фінан- сового правопорядку $\mathrm{EC}$ : держави-члени $\mathrm{EC}$, інституції $\mathrm{CC}$, приватні юридичні особи, фізичні особи; 3) до сучасних тенденцій у фінансовому правопорядку ЄС належать: взаємопроникнення національних фінансових систем держав-членів $€ \mathrm{C}$, мінімізація їхньої автономності, об'єднання фінансових ринків країн СС і формування глобального регіонального фінансового ринку ЄС.

\section{Список літератури:}

1. Яковюк І.В. Правові основи європейської інтеграції та ії вплив на державно-правовий розвиток України : автореф. дис. на здобуття наук. ступеня д-ра юрид. наук : 12.00.11. Харків, 2014. 37 с.

2. Яковюк І.В. Правові основи європейської інтеграції та ії вплив на державно-правовий розвиток : дис. ... д-ра юрид. наук : 12.00.01 / Національний юридичний університет імені Ярослава Мудрого. Харків, 2013. $474 \mathrm{c}$

3. Назаренко О.А. Міжнародна правосуб'єктність Європейського Союзу. Науковий вісник Чернівещъького університету. 2011. Випуск 559. Правознавство. С. 53-57

4. Корнєєв М. В. Фінансовий сектор в умовах фінансіалізації економіки: теоретичні засади та світовий досвід : монографія. Дніпропетровськ : Акцент ПП, 2014. 475 с.

5. Бережна К. В. Проблема міжнародної правосуб'єктності Європейського Союзу. Актуальні проблеми вітчизняної юриспрудениії. 2012. Вип. 3. С. 8-12.

6. Гріненко О. О. ЄС як особливий суб'єкт міжнародного права. Європейське право та порівняльне правознавство : зб. ст. / за ред. Ю.С. Шемшученка. Київ; Шамборі : Логос, 2010. С. 113-127.

7. Консолідовані версії Договору про Свропейський Союз та Договору про функціонування Свропейського Союзу (2010/С 83/01). Офіиійний вісник Свропейського Союзу від 30.03 .2010 p.

8. Угода про фінансування заходу «Програма підтримки енергоефективності в Україні - EE4 U-II» від 13.12.2018 p. URL: https://zakon.rada.gov.ua/laws/ show/984 006-18?lang=ru

9. Кредитна Угода між Україною як Позичальником, Національним банком України як Фінансовим агентом Позичальника та Європейським Союзом як Кредитором від 14.09.2018 p. URL: https://zakon.rada.gov.ua/laws/show/984_002-18

10. Угода про асоціацію між Україною, з однієї сторони, та Європейським Союзом, Європейським співтовариством з атомної енергії і їхніми державами членами, з іншої сторони від 27.06.2014p. URL: https://zakon.rada.gov.ua/ laws/show/984_011

11. Угода про партнерство та співробітництво між Україною і Європейськими Співтовариствами та їх державами-членами від 14.06.1994 p. URL: https://zakon.rada.gov.ua/laws/show/998_012

12. Офіційний сайт OECD. URL: http://www.oecd.org/about/members-and-partners/

13. Право Європейського Союзу : підручник / за ред. В. І. Муравйова. Київ : Юрінком Інтер, 2011. 704 с.

14. Короткий Т. Р. Генезис міжнародної правосуб'єктності інтеграційних утворень і еволюція міжнародного права. Наукові пращчі НУ ОЮА. URL: http:/www.naukovipraci.nuoua.od.ua/arhiv/tom13/ 46.pdf

15. Петришин О. В., Сало I. В. Проблеми реалізації державного суверенітету в економічній та фінансовій сферах в умовах глобалізації і регіональної інтеграції. Державний суверенітет в умовах європейської інтеграиії : монографія / за ред. Ю. П. Битяка, І. В. Яковюка. Київ : Ред. журн. «Право України», 2012. C. 285-313.

16. Рочча Ф. Б. Геоэкономический фактор в финансовых отношениях с зарубежными странами. URL: http://www.novsu.ru/npe/files/um/1412/bg/ shell/arh/stat/staty/Рочча\%20Ф.\%20Геоэкономический\%20фактор\% 20 в \%20 финансовых \%20отношениях\%20c\%20зарубежными \%20странами.htm

17. Толстов С.В., Дікарєв О.І. Європейський Союз як суб’єкт міжнародних відносин. Наукові пращуі МАУП. 2013. Вип. 3(38). С. 60-73.

\section{Vaitsekhovska O.R., Rudenko O.V. THE EUROPEAN UNION AS A SUBJECT OF INTERNATIONAL FINANCIAL LAW AND FEATURES OF ITS FINANCIAL LEGAL ORDER}

The paper analyzes the legal personality of the EU, which received its legal and regulatory basis in 2009 with the entry into force of the Lisbon Treaty. In accordance with the provisions of this Treaty, the member states empower the EU to the extent needed to achieve the common objectives, which it can attain by appropriate means, in conformity with the powers conferred by the Treaty. 
The author examines the peculiarities of the contractual legal personality of the $E U$, which characterizes the ability of the Union to establish rules of international law, including financial legal provisions. The legal and regulatory basis of the contractual legal personality of the EU and the procedures for concluding agreements in the currency sphere are described. The particularities of EU membership in international financial organizations are analyzed as well as suggested types of representation of EU member states and the EU in them.

The research investigates attributes of the financial legal order of the EU, which is based on the implementation of the fundamental principles of free movement of capital, goods, services and persons, most widely embodied within the European Union and their establishment and implementation in the financial sphere are objectively determined by the needs of the development of this regional financial legal order in compliance with the Union's statutory goals.

It is established that the distinguishing traits of the EU financial legal order encompass the following: 1) heterogeneity of the regulatory and legal constituent of the EU financial legal order - the eurozone does not comprise the territory of all EU member states, which creates a different regulatory burden of the EU founding agreements on the monetary policy of EU member states governments; 2) the dualistic nature of EU financial law, the rules of which, on the one hand, have an international contractual formal origin and regulate relations between EU member states in the field of finance, and on the other - are directly applicable to individuals and legal entities; 3) current trends in the EU financial legal order include interpenetration of national financial systems of EU member states, minimization of their autonomy, unification of financial markets of EU countries and the formation of a comprehensive regional EU market.

Key words: financial legal order, international financial law, European Union, international legal personality of the EU. 